\title{
Invasiveness of Yersinia enterocolitica lacking the virulence plasmid: an in-vivo study
}

\author{
C.-J. LIAN, W. S. HWANG*, J. K. KELLY*, and C. H. PAIt
}

Department of Microbiology and Infectious Diseases and "Department of Pathology, University of Calgary Health Sciences Centre, Calgary, Alberta, Canada T2N 4N1

\begin{abstract}
Summary. Rabbits were given, by the intra-gastric route, two isogenic strains of Yersinia enterocolitica that differed only in the presence or absence of the virulence plasmid. Clinical illness and characteristic morphological lesions of $Y$. enterocolitica infection were seen only in rabbits infected with the plasmid-bearing strain (MCH700S). Although rabbits infected with a strain lacking the plasmid (MCH700L) remained healthy, mild histological changes in the small intestine, consisting of epithelial-cell damage, dilatation of lymphatics and a slight increase in neutrophil polymorphonuclear leukocytes in lamina propria, were seen in the first $12 \mathrm{~h}$ after inoculation. Bacteria, which were identified as $Y$. enterocolitica by indirect fluorescent antibody staining, were seen in dilated lymphatics. These early lesions tended to abate quickly and were no longer detectable at $24 \mathrm{~h}$. Strain MCH700L was recovered from the mesenteric lymph nodes in increasing numbers until $24 \mathrm{~h}$ after inoculation; the number then began to decrease rapidly. In contrast, the early lesions in rabbits given strain MCH700S progressed to micro-abscesses, focal destruction of villi, and ulcerations beginning $24 \mathrm{~h}$ after inoculation; the number of bacteria recovered from the lymph nodes continued to increase beyond $24 \mathrm{~h}$ after inoculation. Bacteria were also recovered from the liver and spleen. These results suggest that both plasmidbearing and non-bearing strains of $Y$. enterocolitica are capable of penetrating the intestinal mucosa. However, the virulence plasmid is required for invading bacteria to proliferate in the host tissue and to establish infection.
\end{abstract}

\section{Introduction}

Yersinia enterocolitica is an important cause of gastroenteritis. Histopathological studies of human cases (Bradford et al., 1974) and experimental infection in animals (Carter, 1975; Une, 1977; Pai et al., 1980) have shown that invasion of the intestinal mucosa is of primary importance in pathogenesis. With the recent discovery of a virulence plasmid in $Y$. enterocolitica, attention has been focused on the mode of action of plasmidencoded determinants in pathogenesis (Gemski et al., 1980a; Zink et al., 1980; Portnoy et al., 1981; Portnoy and Martinez, 1985). However, a role for the virulence plasmid in tissue invasion is uncertain.

The invasiveness of $Y$. enterocolitica, as measured by the Sereny test (keratoconjunctival infection of guinea-pigs or rabbits; Sereny, 1955), requires the presence of the virulence plasmid (Zink et al., 1980; Schiemann and Devenish, 1982). On the other

Received 28 Oct. 1986; revised version accepted 10 Feb. 1987 † Correspondence should be sent to Dr C. H. Pai. hand, studies in tissue-culture cells showed that the ability of the organism to penetrate epithelial cells is restricted to certain serotypes or biotypes, but is not associated with the virulence plasmid (Portnoy et al., 1981; Pai and deStephano, 1982; Schiemann and Devenish, 1982). In fact, strains lacking the plasmid have been reported by some investigators to be more invasive to culture cells than plasmidbearing, isogenic strains (Vesikari et al., 1981, 1983; Heesemann et al., 1984). Recently, Bakour et al. (1985) and Robins-Browne et al. (1985) presented evidence that strains lacking the plasmid may also be invasive in vivo. In support of these findings is a report by Isberg and Falkow (1985) that a single chromosomal genetic locus from $Y$. pseudotuberculosis is sufficient to convert Escherichia coli $\mathrm{K} 12$ into an organism capable of invading HEp-2 cells. $Y$. pseudotuberculosis is an invasive pathogen that possesses a virulence plasmid closely related to that of Y. enterocolitica (Gemski et al., 1980b; Bölin et al., 1982; Portnoy and Martinez, 1985).

Recent studies from our laboratory showed that the plasmid-encoded cell-surface components of $Y$. 
enterocolitica act as antiphagocytic factors (Lian and Pai, 1985; Lian et al., 1987). It may be hypothesised that certain serotypes or biotypes of $Y$. enterocolitica are capable of invading the intestinal epithelial cells, irrespective of the presence of the virulence plasmid, but only plasmid-bearing strains can proliferate within the mucosal tissues and induce advanced histopathological changes. Invasive, but plasmid-free strains would be quickly eliminated from the tissues by phagocytosis, leaving no trace of tissue invasion when examined a day or two after oral challenge. The present study was designed to test this hypothesis. Using a rabbit model, we describe the interaction between $Y$. enterocolitica strains and the intestinal tissue at very early stages of infection and the ability of these strains to disseminate to lymphatics and other organs.

\section{Materials and methods}

\section{Bacterial strains}

Two isogenic strains of $Y$. enterocolitica serotype $\mathrm{O}$, biotype 4, MCH700S (plasmid-bearing) and $\mathrm{MCH} 700 \mathrm{~L}$ (plasmid-free), were used in the study. Strain MCH700S was originally isolated from a patient with diarrhoea; strain MCH700L was derived from it by growth on magnesium oxalate agar (Pai and deStephano, 1982). Virulence in experimental infection, invasiveness in tissue-culture cells, and plasmid profiles of the strains have been described previously (Pai and deStephano, 1982; Lian and Pai, 1985).

\section{Infection of rabbits}

The rabbit model developed in our laboratory (Pai et al., 1980) was used to evaluate the invasive capacity of the two isogenic strains. Briefly, New Zealand white rabbits, $0.4-0.7 \mathrm{~kg}$, were deprived of food for $18 \mathrm{~h}$ and were given, by the intra-gastric route through a feeding tube, $10^{10}$ bacterial cells, harvested from an overnight culture on sheep-blood agar incubated at $25^{\circ} \mathrm{C}$, and suspended in $10 \mathrm{ml}$ of $\mathrm{NaHCO}_{3}(10 \% \mathrm{w} / \mathrm{v})$ solution. After infection, the animals were allowed free access to water and food. Two groups of five rabbits, each infected with either strain MCH700S or strain $\mathrm{MCH} 700 \mathrm{~L}$, were observed for 14 days to assess clinical symptoms, weight loss and bacterial shedding. Other groups of five to seven rabbits were killed (one animal at each sampling time) at various times after infection by an overdose of sodium pentobarbital; portions of the mesenteric lymph nodes, spleen, liver, Peyer's patches, small intestine and ileal contents were removed for colony counts or histopathological examination.

\section{Quantitative bacterial cultures}

Tissue samples taken aseptically were placed in a known volume of cold $0.1 \mathrm{M}$ phosphate-buffered saline

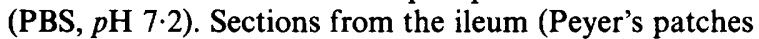
and surrounding gut tissue) were carefully removed, washed three times with cold PBS to remove residual ileal contents, weighed and then placed in a known volume of PBS. Samples were homogenised and serially diluted with PBS, and $0 \cdot 1-\mathrm{ml}$ samples were plated on to MacConkey agar in triplicate for viable counts. Cardiac blood was cultured on sheep-blood agar directly. All plates were incubated at $25^{\circ} \mathrm{C}$ for $48 \mathrm{~h}$. Some representative lactose-negative colonies were confirmed as $Y$. enterocolitica by the API 20E system (Analytab Products, Plainview, NY, USA). To confirm the presence or absence of the virulence plasmid in recovered isolates, randomly-picked colonies were tested for autoagglutination, a character which has been shown to be plasmidmediated (Laird and Cavanaugh, 1980).

\section{Histopathological examination}

Tissue samples for histology were fixed in formaldehyde $4 \% \mathrm{w} / \mathrm{v}$ in phosphate buffer. Segments of intestine were cut open longitudinally and allowed to adhere with the serosal surface on to index cards before fixation in buffered formalin. After fixation, longitudinal sections were taken and carefully embedded in paraffin wax or glycol methacrylate to provide sections perpendicular to the mucosa. Sections were stained with haematoxylin and eosin or Giemsa stain. Tissue for transmission electronmicroscopy was fixed in glutaraldehyde $2.5 \% \mathrm{w} / \mathrm{v}$ in cacodylate buffer $(0.1 \mathrm{M}, p \mathrm{H} 7 \cdot 4)$, post-fixed in osmium tetroxide $2 \% \mathrm{w} / \mathrm{v}$ in cacodylate buffer $(0.1 \mathrm{M}, p \mathrm{H} 7.4)$ for $1 \mathrm{~h}$, dehydrated through graded acetone, and embedded in Epon 812. Sections of $1 \mu \mathrm{m}$ were stained with toluidine blue. Thin sections of selected areas were stained with uranyl acetate and lead acetate and were examined in a Hitachi H-600 electronmicroscope.

Samples used for fluoresence microscopy were fixed in Michel's fixative (Michel et al., 1972). Fixed tissues were washed in Michel's buffer before being snap frozen in liquid nitrogen-cooled isopentane and sectioned in a cryostat. Frozen sections were washed, fixed in absolute methanol, and stained with rabbit hyperimmune sera raised against $Y$. enterocolitica $\mathrm{MCH} 700 \mathrm{~S}$ or $\mathrm{MCH} 700 \mathrm{~L}$ and with fluorescein-conjugated goat anti-rabbit immunoglobulins (Miles Laboratories, Elkhart, IN, USA). Sections were examined with an epifluorescent microscope (Olympus Model BH-2).

\section{Results}

\section{Virulence in rabbits}

Diarrhoea and weight loss were seen in all of five rabbits infected with strain $\mathrm{MCH} 700 \mathrm{~S}$, whereas the five animals infected with strain MCH700L 
continued to gain weight and did not have diarrhoea during the 14-day period of observation. In MCH700S-infected rabbits, cultures of rectal swabs yielded a heavy growth of $Y$. enterocolitica throughol t the observation period. The isolates were autoagglutination-positive, indicating that the virulence plasmid was maintained in vivo. In MCH700L-infected animals, rectal swabs were yielded a light growth of $Y$. enterocolitica only during the first 4 days after inoculation.

\section{Bacterial colonisation}

Colonisation of the intestine by $Y$. enterocolitica was assessed from $4 \mathrm{~h}$ after inoculation by quantitating both free luminal bacteria and tissueassociated bacteria (table I). Strain MCH700S was recovered in large numbers from the Peyer's patches, ileal tissue and ileal contents, and the numbers of bacteria remained steady during the 14-day experimental period. In contrast, strain $\mathrm{MCH} 700 \mathrm{~L}$ was recovered from the same sites in much lower numbers and during only the first 4 days after inoculation.

\section{Invasion}

The capacity of $Y$. enterocolitica strains to invade the intestinal mucosa was assessed by viable counts of mesenteric lymph nodes, spleen, liver and cardiac blood (table II). Both strains were recovered from the mesenteric lymph nodes as early as $1 \mathrm{~h}$ after inoculation and their numbers increased gradually until $24 \mathrm{~h}$. From $24 \mathrm{~h}$ after inoculation, however, counts of strain MCH700L began to decrease and were too low to be detected at $96 \mathrm{~h}$. In contrast, strain MCH700S was recovered from the lymph nodes in increased numbers at $48 \mathrm{~h}$. Only strain

Table I. Recovery of $Y$. enterocolitica strains $\mathrm{MCH} 700 \mathrm{~S}$ and $\mathrm{MCH} 700 \mathrm{~L}$ from the intestinal tissues and luminal contents of rabbits after intragastric administration of $1 \times 10^{10}$ viable bacteria

\begin{tabular}{|c|c|c|c|c|c|c|}
\hline \multirow[b]{3}{*}{$\begin{array}{c}\text { Time after } \\
\text { administration }\end{array}$} & \multicolumn{6}{|c|}{ Number of bacteria $\left(\log _{10} \mathrm{cfu} / \mathrm{g}\right)$ recovered from } \\
\hline & \multicolumn{2}{|c|}{ Peyer's patches } & \multicolumn{2}{|c|}{ Ileal tissue } & \multicolumn{2}{|c|}{ Ileal contents } \\
\hline & MCH700S & $\mathrm{MCH} 700 \mathrm{~L}$ & MCH700S & MCH700L & MCH700S & $\mathrm{MCH} 700 \mathrm{~L}$ \\
\hline 4 hours & $5 \cdot 0$ & ND & $4 \cdot 7$ & ND & $5 \cdot 3$ & ND \\
\hline 1 day & $8 \cdot 1$ & $4 \cdot 7$ & $7 \cdot 0$ & $4 \cdot 7$ & $7 \cdot 6$ & $4 \cdot 7$ \\
\hline 4 days & $6 \cdot 3$ & $2 \cdot 3$ & $6 \cdot 3$ & $2 \cdot 3$ & $6 \cdot 0$ & $1 \cdot 8$ \\
\hline 8 days & $7 \cdot 8$ & 0 & $7 \cdot 3$ & 0 & $7 \cdot 3$ & 0 \\
\hline 14 days & $7 \cdot 2$ & 0 & $6 \cdot 7$ & 0 & $8 \cdot 3$ & 0 \\
\hline
\end{tabular}

$\mathrm{ND}=$ not determined.

Table II. Recovery of $Y$. enterocolitica strains $\mathrm{MCH} 700 \mathrm{~S}$ and $\mathrm{MCH} 700 \mathrm{~L}$ from the internal organs of rabbits after intragastric administration of $1 \times 10^{10}$ viable bacteria

\begin{tabular}{|c|c|c|c|c|c|c|c|c|}
\hline \multirow{3}{*}{$\begin{array}{c}\text { Time after } \\
\text { administration } \\
\text { (h) }\end{array}$} & \multicolumn{8}{|c|}{ Number of bacteria $\left(\log _{10} \mathrm{cfu} / \mathrm{g}\right.$ or $\left.\mathrm{ml}\right)$ recovered from } \\
\hline & \multicolumn{2}{|c|}{$\begin{array}{l}\text { Mesenteric } \\
\text { lymph nodes }\end{array}$} & \multicolumn{2}{|c|}{ Spleen } & \multicolumn{2}{|c|}{ Liver } & \multicolumn{2}{|c|}{$\begin{array}{c}\text { Cardiac } \\
\text { blood }\end{array}$} \\
\hline & $\mathrm{MCH} 700 \mathrm{~S}$ & MCH700L & MCH700S & $\mathrm{MCH} 700 \mathrm{~L}$ & MCH700S & MCH700L & $\mathrm{MCH} 700 \mathrm{~S}$ & $\mathrm{MCH} 700 \mathrm{~L}$ \\
\hline 1 & $2 \cdot 1$ & $2 \cdot 1$ & 0 & 0 & 0 & 0 & 0 & 0 \\
\hline 3 & $2 \cdot 2$ & $1 \cdot 6$ & 0 & 0 & 0 & 0 & 0 & 0 \\
\hline 6 & $2 \cdot 9$ & $2 \cdot 2$ & 0 & 0 & $1 \cdot 8$ & 0 & 0 & 0 \\
\hline 12 & $2 \cdot 9$ & $3 \cdot 6$ & $1 \cdot 7$ & 0 & $1 \cdot 1$ & 0 & 0 & 0 \\
\hline 24 & $4 \cdot 0$ & $4 \cdot 2$ & $1 \cdot 6$ & 0 & $2 \cdot 0$ & 0 & 0 & 0 \\
\hline 48 & $6 \cdot 3$ & $1 \cdot 5$ & 1.6 & 0 & $3 \cdot 3$ & 0 & 0 & 0 \\
\hline 96 & ND & 0 & ND & 0 & ND & 0 & ND & 0 \\
\hline
\end{tabular}

$\mathrm{ND}=$ not determined 
MCH700S was isolated from spleen and liver. Cardiac blood of animals infected with either strain was sterile.

\section{Pathology}

Microscopic intestinal lesions were seen in both groups of rabbits at $1-12 \mathrm{~h}$ after inoculation (early lesions), but only in rabbits given strain $\mathrm{MCH} 700 \mathrm{~S}$ did the lesions increase progressively thereafter; rabbits given strain $\mathrm{MCH} 700 \mathrm{~L}$ displayed little histopathological changes at $24 \mathrm{~h}$ or later. The early lesions consisted of epithelial-cell degeneration (figs. 1 and 2) dilatation of lymphatics (fig. 3), and a slight increase in neutrophil polymorphonuclear leukocytes in lamina propria (fig. 4). The involved epithelial cells appeared lightly stained with disruption of the luminal border or were fragmented showing karyolysis (figs. 1 and 2). Lesions were present in the upper jejunum as early as $1 \mathrm{~h}$ after inoculation and were later seen in the entire small intestine, distributed randomly on the villi and on the surface of Peyer's patches. The histopathological changes, including dilated lymphatics and increase in polymorphonuclear leukocytes, tended to abate from $12 \mathrm{~h}$ after inoculation in rabbits given strain MCH700L. In contrast, rabbits given strain MCH700S showed further histopathological changes, beginning at $24 \mathrm{~h}$ after inoculation, char-

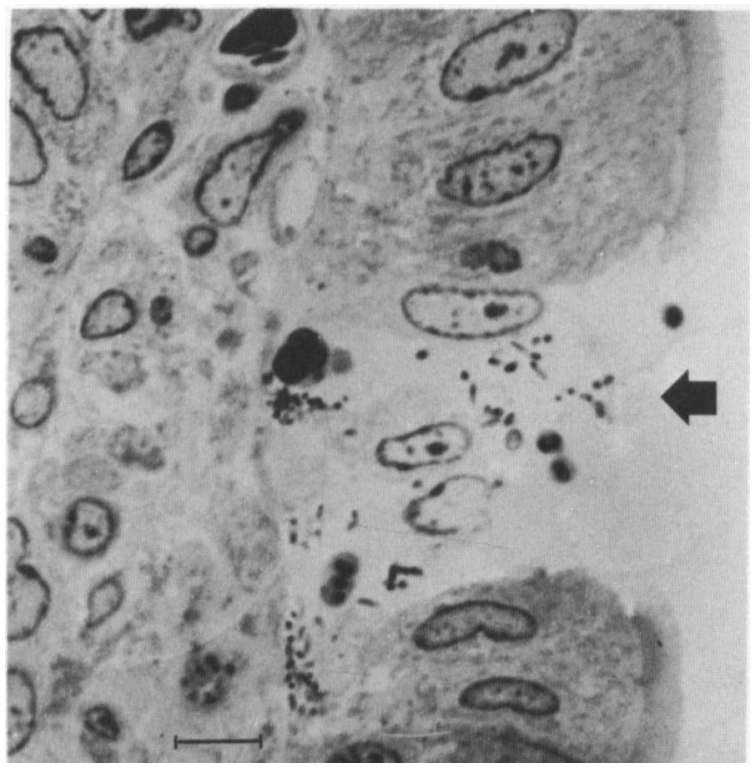

Fig. 1. Upper jejunum of a rabbit infected with strain $\mathrm{MCH} 700 \mathrm{~S}$, $3 \mathrm{~h}$ after inoculation, showing minute focal epithelial-cell damage with the presence of bacteria (arrow). Glycol methacrylate section; Giemsa stain. Bar $=10 \mu \mathrm{m}$.

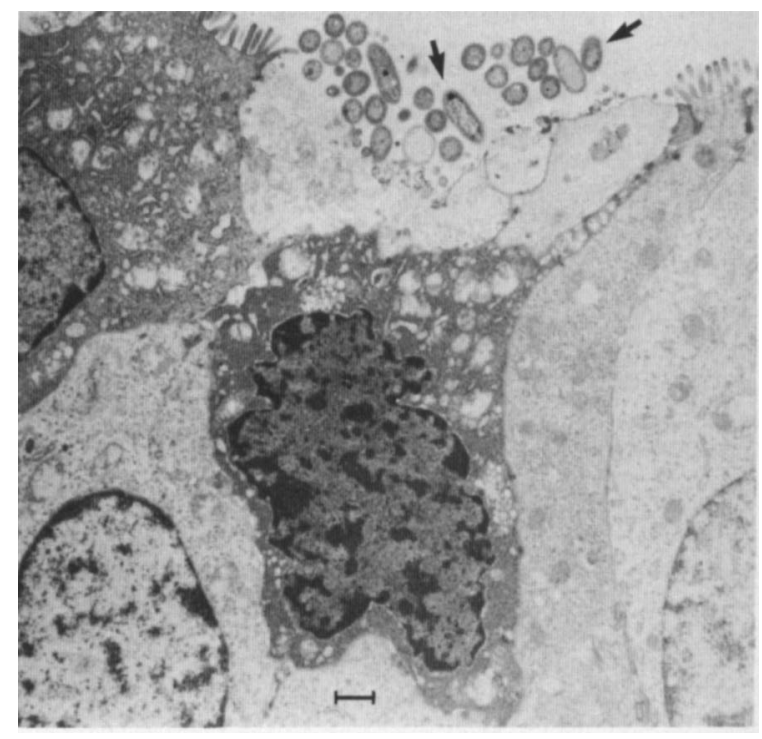

Fig. 2. Electronmicrograph of upper jejunum of a rabbit infected with strain $\mathrm{MCH} 700 \mathrm{~L}, 3 \mathrm{~h}$ after inoculation, showing lysis of cell membrane and destruction of microvilli associated with presence of bacteria (arrows). Bar $=1 \mu \mathrm{m}$.

acterised by the progression of the early lesion to the presence of bacterial clumps with formation of micro-abscesses, associated with focal destruction of villi and ulceration. These advanced lesions were most prominent in the ileum, particularly in Peyer's patches and surrounding tissues (fig. 5).

By light microscopy and electronmicroscopy, bacteria were sometimes seen associated with damaged epithelial cells and in dilated lymphatics of villi in rabbits given MCH700S and MCH700L (figs, 1, 2, and 3). With indirect fluorescent-antibody staining, brightly fluorescent yellow-green bacteria were seen, both on the epithelial lining and in lamina propria of both groups of rabbits (fig. 6). However, in rabbits infected with strain MCH700S, increasing numbers of bacteria were seen in the epithelial layers, lamina propria and Peyer's patches with time, while in rabbits infected with strain $\mathrm{MCH} 700 \mathrm{~L}$, bacteria were rarely seen in lamina propria from $24 \mathrm{~h}$ after infection. Electronmicroscopy of MCH700S-infected rabbit sections at $24 \mathrm{~h}$ after inoculation showed micro-colonies of bacteria surrounded by polymorphonuclear leukocytes without any evidence of the bacteria being phagocytosed (fig. 7).

Sections of mesenteric lymph nodes, liver and spleen were also examined for histological changes. In rabbits infected with strain $\mathrm{MCH} 700 \mathrm{~S}$, microabcesses with clumps of bacteria interspersed with inflammatory cells were seen in mesenteric lymph 


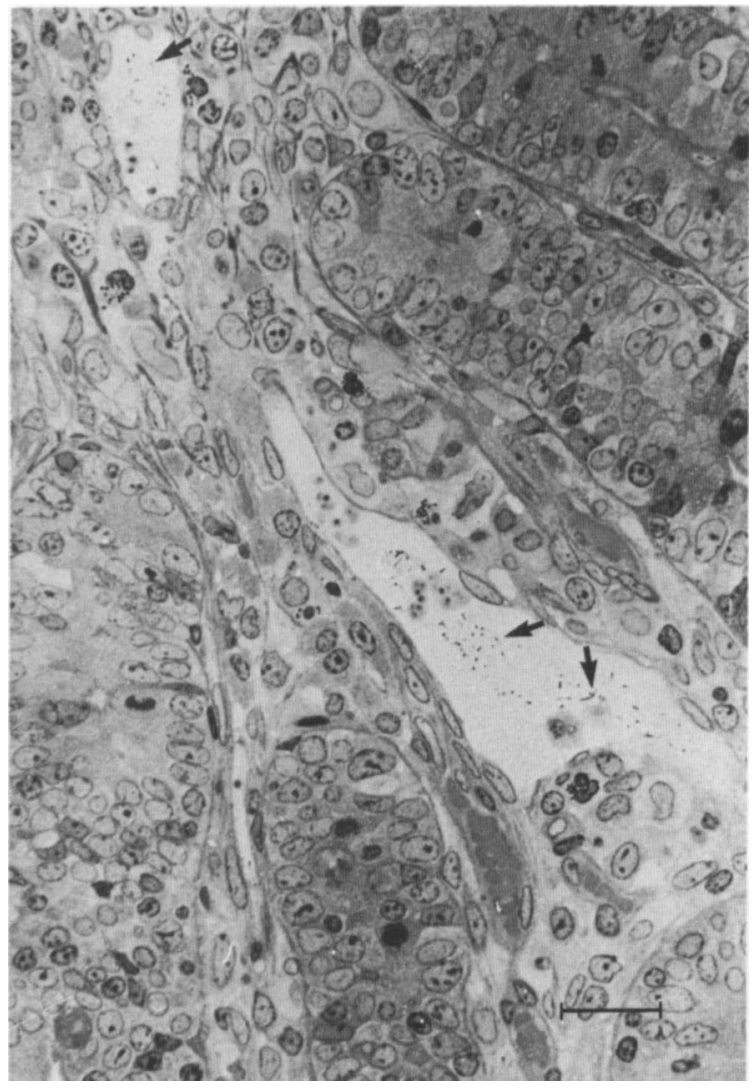

Fig. 3. Dilated lymphatics containing bacteria (arrows) in lamina propria of upper jejunum of a rabbit infected with strain $\mathrm{MCH} 700 \mathrm{~S}, 4 \mathrm{~h}$ after inoculation. Glycol methacrylate section; Giemsa stain. Bar $=20 \mu \mathrm{m}$.

nodes beginning at $24 \mathrm{~h}$ after infection. Little histopathological change was detected in the liver and spleen. No significant abnormality was seen at any time in the above tissues from rabbits given strain MCH700L.

\section{Discussion}

In this study, we have presented evidence that a $Y$. enterocolitica strain (MCH700L) lacking the virulence plasmid is capable of penetrating the intestinal mucosa of rabbits, although the strain failed to produce clinical illness and advanced histopathological changes in the animal. This conclusion was based on the following observations: (i) a significant number of viable bacteria was recovered from the mesenteric lymph nodes; (ii) histopathological changes were seen, including epithelial-cell damage, dilatation of lymphatics and a slight increase in inflammatory cells in lamina propria; (iii) bacteria were seen associated with the damaged epithelial cells and in dilated lymphatics; and (iv) indirect immunofluorescent staining showed the presence of $Y$. enterocolitica within lamina propria. It should be noted, however, that the mucosal invasion by strain $\mathrm{MCH} 700 \mathrm{~L}$, unlike the invasion by the plasmid-bearing strain (MCH700S), did not result in advanced inflammatory lesions in lamina propria and Peyer's patches, nor invasion beyond the mesenteric lymph nodes. Mild histopathological changes seen in rabbits infected with strain $\mathrm{MCH} 700 \mathrm{~L}$ were limited to those sections taken during the first $12-24 \mathrm{~h}$ after infection, and histological findings were without any abnormality after $24 \mathrm{~h}$. Furthermore, occasional bacteria seen in lamina propria up to $12 \mathrm{~h}$ after infection were no longer detectable after $24 \mathrm{~h}$. In contrast, rabbits infected with strain MCH700S showed progressive lesions with micro-abscess formation, villus destruction and ulceration, and bacteria were recovered in increasing numbers from the mesenteric lymph nodes, as well as from the liver and spleen.

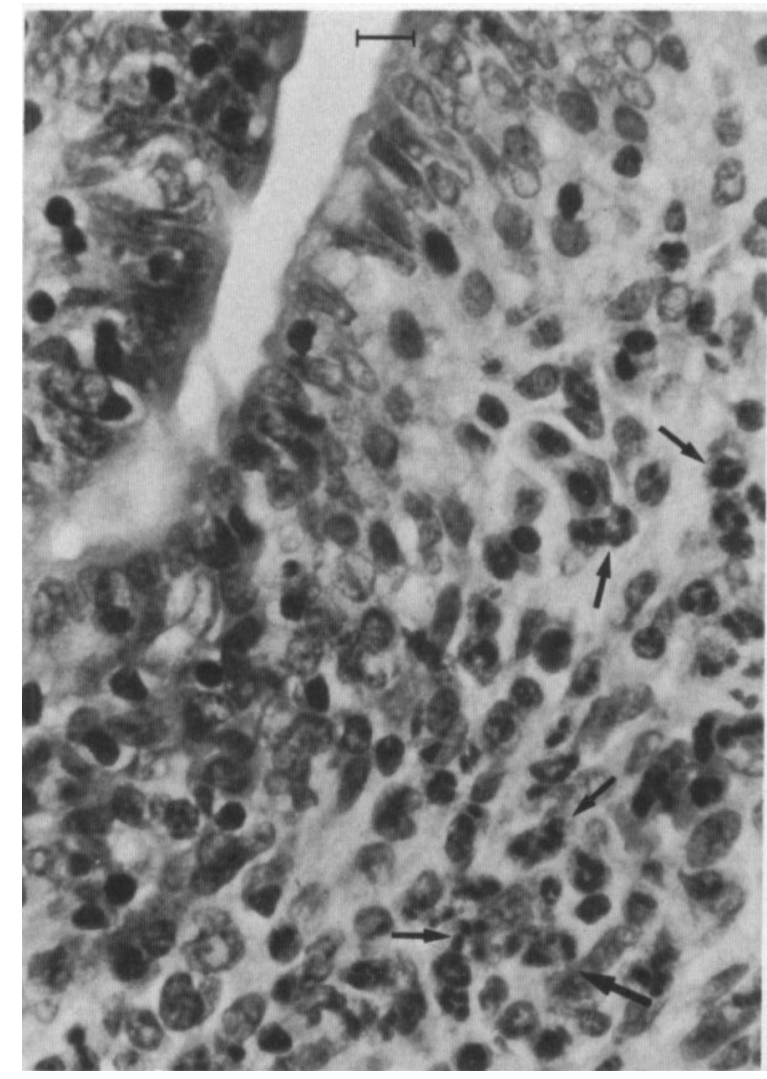

Fig. 4. Mild acute inflammatory response in lamina propria as shown by presence of polymorphonuclear leukocytes (arrows) in a rabbit infected with strain $\mathrm{MCH} 700 \mathrm{~L}, 3 \mathrm{~h}$ after inoculation. Paraffin section; haematoxylin and eosin stain. Bar $=10 \mu \mathrm{m}$. 


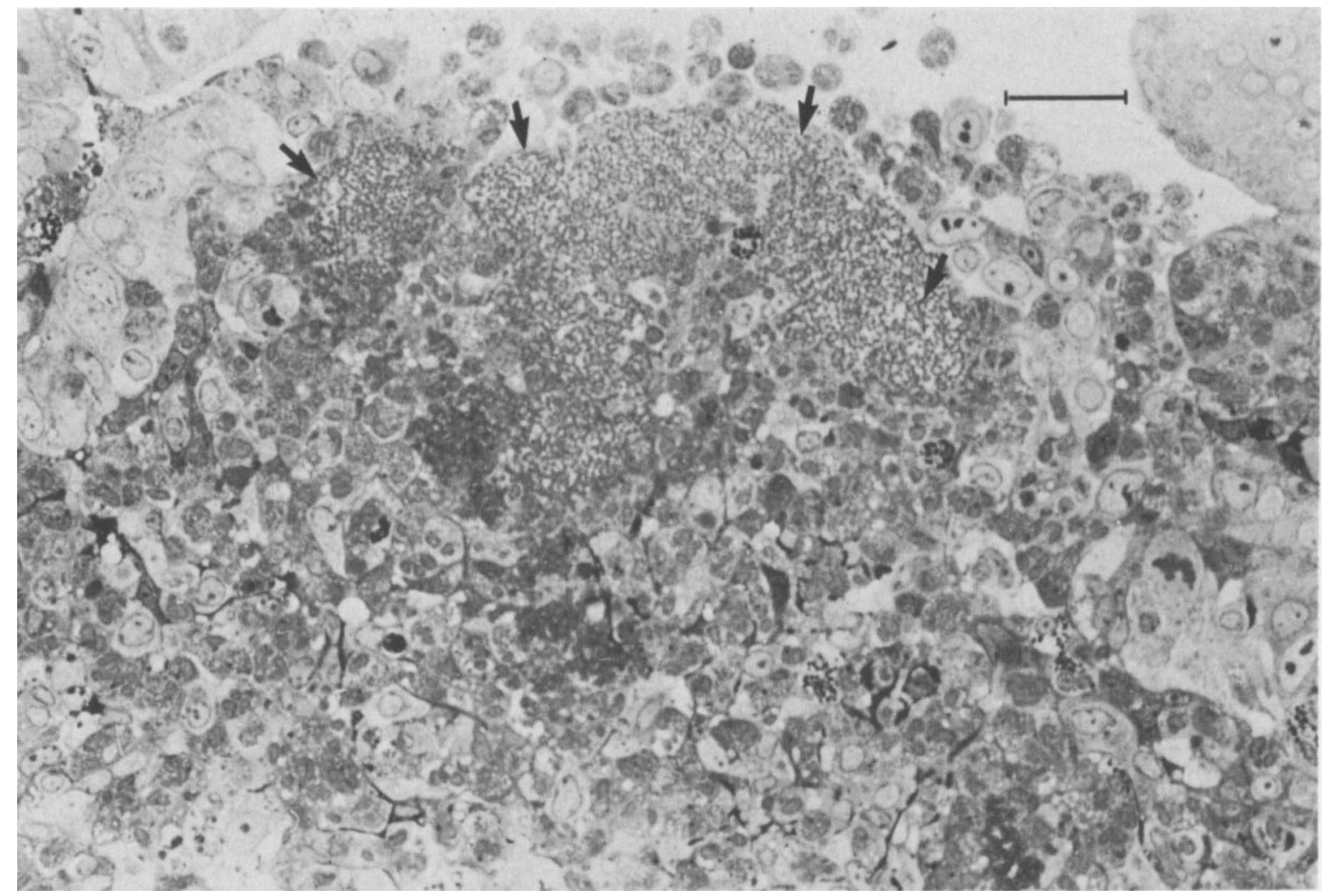

Fig. 5. Advanced lesions in Peyer's patches and surrounding tissues $24 \mathrm{~h}$ after inoculation of strain MCH700S, showing bacterial clumps (arrows) with formation of micro-abscesses, destruction of villi and ulceration. Glycol methacrylate section; Giemsa stain. $\mathrm{Bar}=20 \mu \mathrm{m}$.

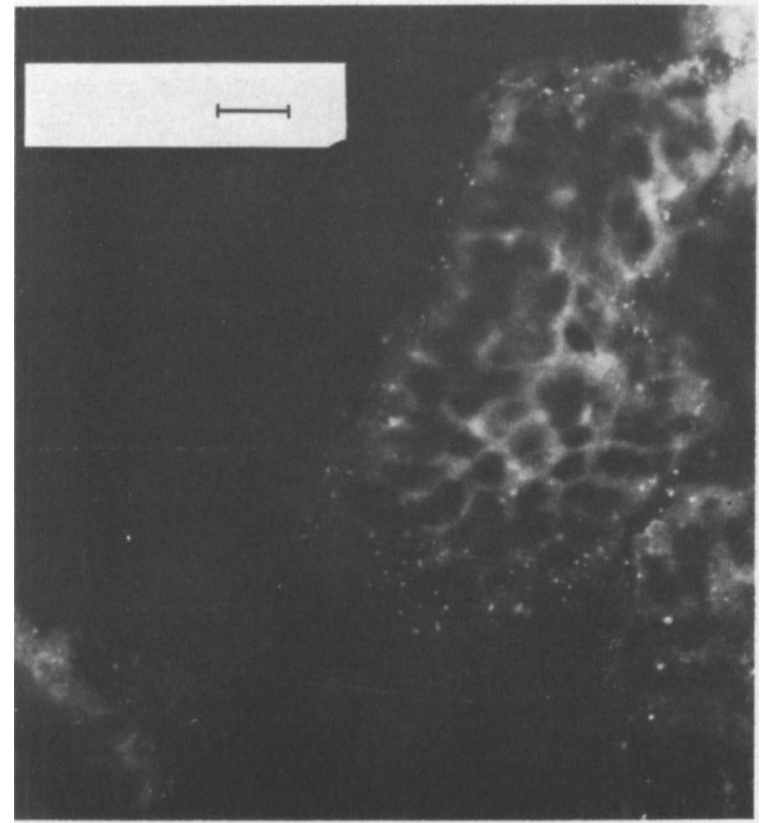

Fig. 6. Fluorescent antibody stain showing presence of $Y$. enterocolitica on epithelial surface and in lamina propria, $12 \mathrm{~h}$ after inoculation of strain MCH700L. Bar $=20 \mu \mathrm{m}$.

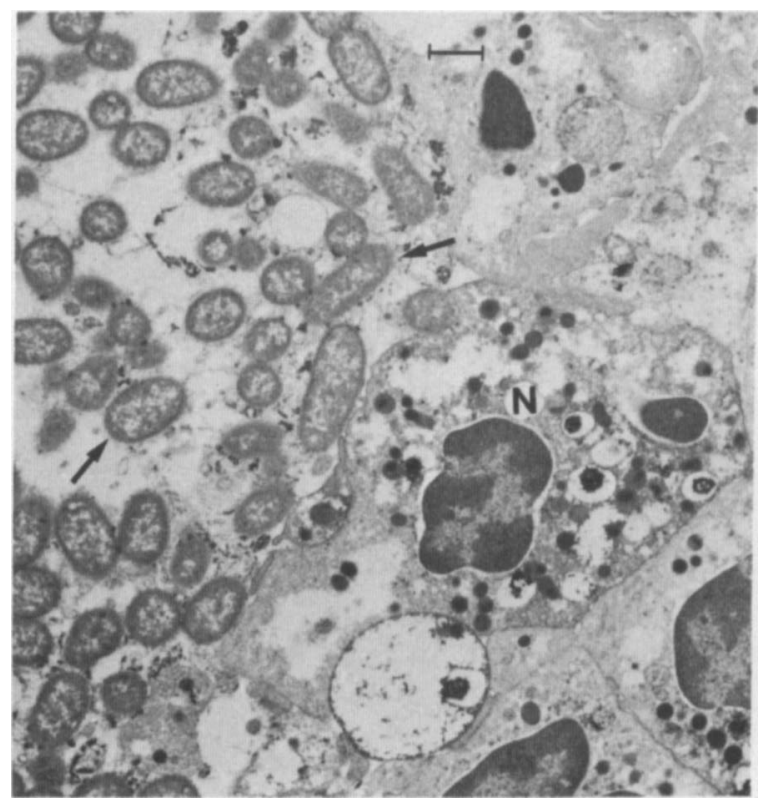

Fig. 7. Electronmicrograph of Peyer's patch in distal ileum $24 \mathrm{~h}$ after inoculation of strain MCH700S. Bacteria (arrows) are in close contact with neutrophils $(\mathrm{N})$ with no evidence of being ingested. Bar $=1 \mu \mathrm{m}$. 
The present study confirms the recent reports by Bakour et al. (1985) and Robins-Browne et al. (1985) that strains of $Y$. enterocolitica lacking the virulence plasmid invade the intestinal mucosa. Plasmid-free strains of $Y$. enterocolitica were recovered from the mesenteric lymph nodes of mice (Bakour et al., 1985) and the mesenteric lymph nodes, liver and spleen of gnotobiotic piglets (Robins-Browne et al., 1985). Furthermore, anti- $Y$. enterocolitica antibodies were detected in the sera of mice challenged orally with a plasmid-free strain (Bakour et al., 1985). The present study shows also, for the first time, that infection with a plasmid-free strain produced mild early histopathological changes in the intestinal mucosa. In other experimental infections, histological examinations were not performed until $24 \mathrm{~h}$ after inoculation or later (Robins-Browne et al., 1985). The histopathological changes seen in this study in rabbits infected with the plasmid-free strain would have been missed completely if the first necropsy had not been performed until $24 \mathrm{~h}$ after inoculation. The presence of bacteria in lamina propria would not have been easily observed at that time. Also, the use of glycol methacrylate sections (figs. 1 and 3 ) in our study would enhance the detection of early epithelial changes and of the prasence of bacteria because of better resolution afforded by these plastic-embedded sections.

That invasiveness of the gut epithelium by $Y$. enterocolitica is not a plasmid-associated event is consistent with the in-vitro finding that plasmidfree strains were as invasive as plasmid-bearing parent strains in tissue cultures (Portnoy et al., 1981; Vesikari et al., 1981; Pai and deStephano, 1982; Schiemann and Devenish, 1982; Vesikari et al., 1983; Heesemann et al., 1984). The virulence factor(s) encoded by the plasmid may, therefore, appear to decide the fate of the organism subsequent to the mucosal invasion. The plasmid-free strain appears to be unable to proliferate in the tissue and to establish destructive loci in lamina propria and Peyer's patches. In contrast, the plasmid-bearing strain continues to multiply and forms microcolonies, causing severe inflammatory responses and tissue destruction. In these foci, bacteria were found surrounded by, or interspersed with, inflammatory cells, but there was little evidence that the bacteria were being phagocytosed. These observations support our recent finding that plasmidencoded cell-surface components of $Y$. enterocolitica act as antiphagocytic factors (Lian and Pai, 1985; Lian et al., in press). It appears that the ability of $Y$.enterocolitica to penetrate the intestinal epithelial cells is not associated with the virulence plasmid, but only plasmid-bearing strains are capable of proliferating within host tissues and establishing infection because of their resistance to phagocytosis, which is a plasmid-associated character.

We thank Gwyneth Meyers, Catherine Scott, and Ibolya Gedeon for technical assistance and Shirley Eikerman for secretarial assistance. This work was supported by grant MA 7108 from the Medical Research Council of Canada. C.-J. L. is a recipient of an Alberta Heritage Foundation for Medical Research studentship.

\section{REFERENCES}

Bakour R, Balligand G, Laroche Y, Cornelis G, Wauters G 1985 A simple adult-mouse test for tissue invasiveness in Yersinia enterocolitica strains of low experimental virulence. Journal of Medical Microbiology 19: 237-246.

Bölin I, Norlander L, Wolf-Watz H 1982 Temperature-inducible outer membrane protein of Yersinia pseudotuberculosis and Yersinia enterocolitica is associated with the virulence plasmid. Infection and Immunity 37:506-512.

Bradford W D, Noce P S, Gutman L T 1974 Pathologic features of enteric infection with Yersinia enterocolitica. Archives of Pathology $98: 17-22$.

Carter P B 1975 Pathogenicity of Yersinia enterocolitica for mice. Infection and Immunity 11 : 164-170.

Gemski P, Lazere J R, Casey T 1980a Plasmid associated with pathogenicity and calcium dependency of Yersinia enterocolitica. Infection and Immunity 27:682-685.

Gemski P, Lazere J R, Casey T, Wohlhieter J A $1980 b$ Presence of a virulence-associated plasmid in Yersinia pseudotuberculosis. Infection and Immunity 28 : 1044-1047.

Heesemann J, Algermissen B, Laufs R 1984 Genetically manipulated virulence of Yersinia enterocolitica. Infection and Immunity 46: 105-110.

Isberg R R, Falkow S 1985 A single genetic locus encoded by Yersinia pseudotuberculosis permits invasion of cultured animal cells by Escherichia coli K-12. Nature 317:262-264.

Laird W J, Cavanaugh D C 1980 Correlation of autoagglutination and virulence of yersiniae. Journal of Clinical Microbiology 11 : 430-432.

Lian C-J. Hwang W S, Pai C H Plasmid-mediated resistance to phagocytosis in Yersinia enterocolitica. Infection and Immunity in press.

Lian C-J, Pai C H 1985 Inhibition of human neutrophil chemiluminescence by plasmid-mediated outer membrane proteins of Yersinia enterocolitica. Infection and Immunity 49: 145-151.

Michel B, Milner Y, David K 1972 Preservation of tissue-fixed immunoglobulins in skin biopsies of patients with lupus erythematosus and bullous diseases-preliminary report. Journal of Investigative Dermatology $59: 449-452$.

Pai C H, deStephano L 1982 Serum resistance associated with virulence in Yersinia enterocolitica. Infection and Immunity $35: 605-611$.

Pai C H, Mors V, Seemayer T A 1980 Experimental Yersinia enterocolitica enteritis in rabbits. Infection and Immunity 28: $238-244$.

Portnoy D A, Moseley S L, Falkow S 1981 Characterization of plasmids and plasmid-associated determinants of Yersinia 
enterocolitica pathogenesis. Infection and Immunity 31 : 775 782.

Portnoy D A, Martinez R J 1985 Role of a plasmid in the pathogenicity of Yersinia species. Current Topics in Microbiology and Immunology 118:29-51.

Robins-Browne R M, Tzipori S, Gonis G, Hayes J, Withers M, Prpic J K 1985 The pathogenesis of Yersinia enterocolitica infection in gnotobiotic piglets. Journal of Medical Microbiology 19 : 297-308.

Schiemann D A, Devenish J A 1982 Relationship of HeLa cell infectivity to biochemical, serological and virulence characteristics of Yersinia enterocolitica. Infection and Immunity $35: 497-506$.

Serény B 1955 Experimental Shigella keratoconjunctivitis: a preliminary report. Acta Microbiologica Academiae Scientiarum Hungaricae (Budapest) 2: 293-296.

Une T 1977 Studies on the pathogenicity of Yersinia enterocolitica. I. Experimental infection in rabbits. Microbiology and Immunology 21 :349-363.

Vesikari T et al. 1981 Plasmids in Yersinia enterocolitica serotypes $0: 3$ and 0:9: Correlation with epithelial cell adherence in vitro. Infection and Immunity 33:870-876.

Vesikari T, Sundqvist C, Mäki M 1983 Adherence and toxicity of Yersinia enterocolitica $0: 3$ and $0: 9$ containing virulenceassociated plasmids for various cultured cells. Acta Pathologica et Microbiologica Scandinavica Section B. 91 : 121-127.

Zink D L et al. 1980 Plasmid-mediated tissue invasiveness in Yersinia enterocolitica. Nature 283: 224-226. 